\title{
SYNTHESIS, SPECTRAL STUDIES, ANTI-OXIDANT, ANTI- INFLAMMATORY AND ANTIBACTERIAL ACTIVITIES OF 3-(1H-INDOL-3-YL)-1-PHENYLPROP-2-EN-1-ONE DERIVATIVES
}

\author{
B. Premalatha ${ }^{1, \bowtie}$ and P. Ramanathan ${ }^{2}$ \\ ${ }^{1}$ PG \& Research Department of Chemistry, Government Arts College, C. Mutlur - 608102, \\ (Tamilnadu) India \\ ${ }^{2}$ PG \& Research Department of Chemistry, Thanthai Hans Roever College (Autonomous), \\ Perambalur - 621220, (Tamilnadu) India \\ ${ }^{{ }^{凶}}$ Corresponding Author: premalatha.au18@yahoo.in
}

\begin{abstract}
The 3-(1H-indol-3-yl)-1-phenylprop-2-en-1-one derivatives were synthesized by conventional method. The compounds are analyzed by IR, NMR, mass spectral and anti-oxidant, anti-inflammatory and antimicrobial activities are carried out. The studies identify the active compounds accountable for anti-oxidants and antiinflammatory. Studies are extremely required for future drug growth.
\end{abstract}

Keywords: IR, NMR, Anti-oxidant, Anti-inflammatory, Antimicrobial.

RASĀYAN J. Chem., Vol. 14, No.1, 2021

\section{INTRODUCTION}

Indole derivatives are very significant heterocyclic compounds that induced several biological activities $^{1,2}$. Indole derivatives via palladium-catalyzed hetero annulation of alkynes by Amides with ethyl diazoacetate ${ }^{3-5} . N$-substituted anilines and alkanolamines ${ }^{6}, 5 \alpha$-androstane-3,17-dione with 1methyl-1-phenylhydrazine ${ }^{7,8}$. The grounding of (Z)-16- (7-aza-1H-indol-1-yl) methylene-17oxoandrost-5-en-3 $\beta$-yl-acetate by the response of 17-chloro-16-formylandrosta-5,16- dien-3-yl acetate with 7 -azaindole under $\mathrm{N}_{2}$ atmosphere $^{9}$, Antiallergic ${ }^{10}$, anticancer ${ }^{11}$, anti-inflammatory ${ }^{12}$, antimalarial ${ }^{13}$, antitubercular ${ }^{14}$, antiviral ${ }^{15}$. Indole scaffold have been establishing in several important artificial drug molecules which give a precious plan for treatment and binds with elevated similarity to the multiple receptors helpful in developing novel useful derivatives ${ }^{16-18}$.

\section{EXPERIMENTAL}

\section{Measurements}

IR spectra were recorded in AVATAR-330 FT-IR spectrophotometer. ${ }^{1} \mathrm{H}$ and ${ }^{13} \mathrm{C}$ NMR recorded on BRUKER AMX working at $300 \mathrm{MHz}$.

\section{Synthesis of 3-(1H-indol-3-yl)-1-phenylprop-2-en-1-one Derivatives}

A combination of indole-3-cabamaldehyde $(1 \mathrm{mmol})$, substituted acetophenone $(1 \mathrm{mmol})$ and $20 \mathrm{~mL}$ of ethanol to be added into a refluxing flask and few grams of sodium methoxide was added and refluxed for $4 \mathrm{hrs}$ at $75^{\circ} \mathrm{C}$ and this combination was monitored by TLC (Scheme 1). The final mass was transfer into ice-cold water to the removal of unreacted aldehyde. The residue was obtained and purified by chromatography technique by using benzene: chloroform mixture $(8: 2)$ as an eluent.

\section{Anti-Oxidant Studies}

\section{DPPH Scavenging Assay}

The ability to scavenging the stable free radical, DPPH (2,2-diphenyl-1-picryl-hydrazyl-hydrate) free radical method is an antioxidant assay was measured as a decrease in absorbance at $517 \mathrm{~nm}$ by the method.

\section{Procedure}

Methanolic solution of DPPH $(90.30 \mathrm{mM})$, an identical volume of ethanolic Rhizome of Cyperus rotundus L $(250-1500 \mu \mathrm{g})$ was added and prepared up to $1.0 \mathrm{~mL}$ with methanol DPPH. The solutions 
were stunned well \& made to stand the solutions at room temperature for $30 \mathrm{~min}$. The absorbance was examined at $517 \mathrm{~nm}$ in UV-VIS spectrophotometer as ascorbic acid employed as reference. If the absorbance value is low means then the free-of-charge scavenging activity will be very high.

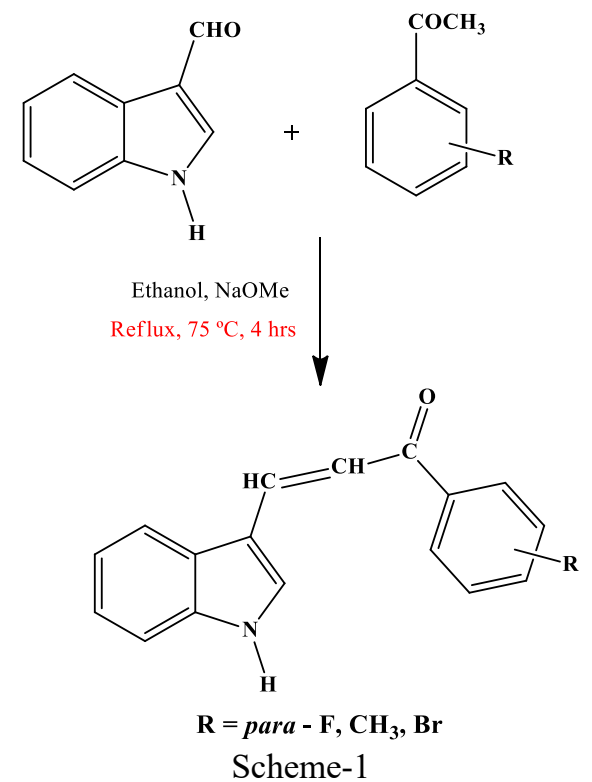

The scavenging DPPH radical activity was calculated by utilizing the given principle-

DPPH Scavenging Effect (\% Inhibition) $=\left[\mathrm{A}_{0}-\mathrm{A}_{\mathrm{t}} \mathrm{A}_{0}\right] \times 100$

Where, $\mathrm{A}_{0}=$ absorbance of the control and $\mathrm{A}_{\mathrm{t}}=$ absorbance of tested samples at a particular time. $\mathrm{IC}_{50}$ $=$ concentration of the compound required to inhibit $50 \%$ of DPPH production.

\section{Anti-inflammatory Activity}

The reaction was consisting of test extracts and $1 \%$ solution of bovine albumin fraction, $\mathrm{pH}$ of the reaction was used to a little amount at $37{ }^{\circ} \mathrm{C} \mathrm{HCl}$. The extracts were incubated at $37{ }^{\circ} \mathrm{C}$ for 20 min and then animated to $51{ }^{\circ} \mathrm{C}$ for $20 \mathrm{~min}$ after cooling the turbidity was deducted spectrophotometrically at $660 \mathrm{~nm}$. Diclofenac sodium was used as a standard drug.

Percentage of inhibition $=($ OD of Control - OD of Sample $/$ OD of Control $) X 100$.

\section{Antibacterial Studies}

Bacterial filters Viz., E. coli, S. aureus are engaged in these activities and Chloromphenicol is used as standard.

\section{IR and NMR Spectral Analysis}

\section{3-(1H-indol-3-yl)-1-phenylprop-2-en-1-one (1)}

From the spectrum 3-(1H-indol-3-yl)-1-phenylprop-2-en-1-one the C=O, N-H; 1599, 3440-3354 cm $\mathrm{C}-\mathrm{N} ; 2361 \mathrm{~cm}^{-1}$; CH, C=C; 2921-2850, $1508 \mathrm{~cm}^{-1}$; C-O; $1168 \mathrm{~cm}^{-1}$.

Molecular formula: $\mathrm{C}_{18} \mathrm{H}_{13} \mathrm{NO}:{ }^{1} \mathrm{H} \&{ }^{13} \mathrm{C} \mathrm{NMR}\left(300 \mathrm{MHz}, \mathrm{CDCl}_{3}\right)$ : $\delta, 10.04$ (s, 1H), 8.32 (q, J = 9.0 $\mathrm{Hz}, 1 \mathrm{H}), 8.142-7.956(\mathrm{~m}, 3 \mathrm{H}), 7.83(\mathrm{~d}, \mathrm{~J}=7.3 \mathrm{~Hz}, 1 \mathrm{H}), 7.63-7.43(\mathrm{~m}, 1 \mathrm{H}), 7.33(\mathrm{q}, 3 \mathrm{H}) ; \delta 111.77$, $112.07,113.21,116.26,118.48,119.97,120.90,121.11,122.06,122.56,123.38,124.12,125.01$, 127.82, 127.94, 128.81, 131.12, 136.03, 136.43, 136.92, 137.41, 138.79, 142.45, 189.97. MS: m/z. $247.29[\mathrm{M}+]$.

\section{1-(4-fluorophenyl)-3-(1H-indol-3-yl)prop-2-en-1-one (2)}

From the spectrum 1-(4-fluorophenyl)-3-(1H-indol-3-yl)prop-2-en-1-one the $\mathrm{C}=\mathrm{O}, \mathrm{N}-\mathrm{H} ; 1629,3358$ $3246 \mathrm{~cm}^{-1}$; $\mathrm{CH}, \mathrm{CH}=\mathrm{CH} ; 3162,3073 \mathrm{~cm}^{-1}$; C-F, C-O; 1221, $1041 \mathrm{~cm}^{-1}$.

Molecular formula: $\mathrm{C}_{17} \mathrm{H}_{12} \mathrm{FNO}:{ }^{1} \mathrm{H} \&{ }^{13} \mathrm{C}$ NMR $\left(300 \mathrm{MHz}, \mathrm{CDCl}_{3}\right): \delta, 10.04(\mathrm{~s}, 1 \mathrm{H}), 8.35$ (q, $\mathrm{J}=9.0$ $\mathrm{Hz}, 1 \mathrm{H}), 8.142-7.956(\mathrm{~m}, 2 \mathrm{H}), 7.81(\mathrm{~d}, \mathrm{~J}=7.1 \mathrm{~Hz}, 1 \mathrm{H}), 7.66-7.45(\mathrm{~m}, 4 \mathrm{H}), 7.33(\mathrm{q}, 3 \mathrm{H}) ; \delta 111.74$, $112.07,113.21,116.26,118.48,119.97,120.90,121.19,122.06,122.56,123.38,124.12,125.01$, 
127.82, 127.94, 128.84, 131.12, 136.03, 136.43, 136.92, 137.41, 138.79, 142.45, 189.77. MS: m/z. $265.28[\mathrm{M}+]$.

\section{3-(1H-indol-3-yl)-1-(p-tolyl)prop-2-en-1-one (3)}

From the spectrum 3-(1H-indol-3-yl)-1-(p-tolyl)prop-2-en-1-one the $\mathrm{C}=\mathrm{O}, \mathrm{N}-\mathrm{H} ; 1646,3387-3357 \mathrm{~cm}^{-}$ ${ }^{1}$; C-N, $\mathrm{HC}=\mathrm{CH} ; 2321,3055 \mathrm{~cm}^{-1}$; C-H, C=C; 3225, $1511 \mathrm{~cm}^{-1}$; C-O; $1042 \mathrm{~cm}^{-1}$.

Molecular formula: $\mathrm{C}_{18} \mathrm{H}_{15} \mathrm{NO}:{ }^{1} \mathrm{H} \&{ }^{13} \mathrm{C}$ NMR $\left(300 \mathrm{MHz}, \mathrm{CDCl}_{3}\right): \delta, 10.05(\mathrm{~s}, 1 \mathrm{H}), 8.08-7.933(\mathrm{~m}$, $3 \mathrm{H}), 7.82(\mathrm{~d}, \mathrm{~J}=6.3 \mathrm{~Hz}, 2 \mathrm{H}), 7.60(\mathrm{q}, 2 \mathrm{H}), 7.46-7.26(\mathrm{~m}, 6 \mathrm{H}), 2.42(\mathrm{~s}, 3 \mathrm{H}) ; \delta 25.11,111.09,111.32$, $112.04,112.44,112.53,114.77,117.40,119.01,119.98,120.06,121.07,121.59,122.41,123.19$, 124.16, 129.11, 129.21, 130.41, 130.49, 136.12, 136.58, 137.29, 183.66. MS: m/z. 261.32 [M+].

\section{1-(4-bromophenyl)-3-(1H-indol-3-yl)prop-2-en-1-one (4)}

From the spectrum 1-(4-bromophenyl)-3-(1H-indol-3-yl)prop-2-en-1-one the $\mathrm{C}=\mathrm{O}, \mathrm{N}-\mathrm{H} ; 1626,3416-$ $3357 \mathrm{~cm}^{-1}$; C-H, C=C; 3208-3177, $1568 \mathrm{~cm}^{-1}$; C=C, C-C; 3067, 2819-2782 cm${ }^{-1}$; C-O; $1121 \mathrm{~cm}^{-1}$; C$\mathrm{Br} ; 670 \mathrm{~cm}^{-1}$.

Molecular formula: $\mathrm{C}_{17} \mathrm{H}_{12} \mathrm{BrNO}:{ }^{1} \mathrm{H} \&{ }^{13} \mathrm{C}$ NMR $\left(300 \mathrm{MHz}, \mathrm{CDCl}_{3}\right): \delta, 10.05(\mathrm{~s}, 1 \mathrm{H}), 8.08-7.933(\mathrm{~m}$, $3 \mathrm{H}), 7.80(\mathrm{~d}, \mathrm{~J}=6.3 \mathrm{~Hz}, 2 \mathrm{H}), 7.60(\mathrm{q}, 2 \mathrm{H}), 7.46-7.26(\mathrm{~m}, 6 \mathrm{H}) ; \delta 111.19,111.32,112.24,112.44$, $112.56,114.77,117.42,119.11,119.99,120.06,121.17,121.59,122.44,123.19,124.26,129.15$, 129.26, 130.47, 130.52, 136.14, 136.58, 137.33, 183.69. MS: m/z. $326.19[\mathrm{M}+]$.

\section{RESULTS AND DISCUSSION}

\section{Anti - Oxidant Activity}

\section{DPPH Scavenging Assay Method}

Though there are many methods available to assess the antioxidant activity of compounds, DPPH scavenging assay method is an easy and rapid method. DPPH method is also a receptive method for the antioxidant screening of synthesized organic compounds.

It is obvious beginning the data shown in Table-1 and Fig.-1. The compound $\mathbf{1}$ of the result shows the fraction of cytotoxicity for $250 \mathrm{mg} / \mathrm{ml}$ as $12.09 \%, 500 \mathrm{mg} / \mathrm{ml}$ as $34 \%$ and $750 \mathrm{mg} / \mathrm{ml}$ as $36 \%$ and $1000 \mathrm{mg} / \mathrm{ml}$ as $48 \%$. The compound 2 of the result shows cytotoxicity for $250 \mathrm{mg} / \mathrm{ml}$ as $13.25 \%, 500$ $\mathrm{mg} / \mathrm{ml}$ as $26.5 \%$ and $750 \mathrm{mg} / \mathrm{ml}$ as $44.2 \%$ and $1000 \mathrm{mg} / \mathrm{ml}$ as $50.3 \%$. The compound 3 of the result shows the \% of cytotoxicity for $250 \mathrm{mg} / \mathrm{ml}$ as $12.3 \%, 500 \mathrm{mg} / \mathrm{ml}$ as $18.5 \%$ and $750 \mathrm{mg} / \mathrm{ml}$ as $24.3 \%$ and $1000 \mathrm{mg} / \mathrm{ml}$ as $34 \%$. The compound 4 of the result shows cytotoxicity for $250 \mathrm{mg} / \mathrm{ml}$ as $16 \%, 500$ $\mathrm{mg} / \mathrm{ml}$ as $19.2 \%$ and $750 \mathrm{mg} / \mathrm{ml}$ as $27 \%$ and $1000 \mathrm{mg} / \mathrm{ml}$ as $43 \%$. These inhibition values are compared with Ascorbic acid for $250 \mathrm{mg} / \mathrm{ml}$ as $23.63 \%, 500 \mathrm{mg} / \mathrm{ml}$ as $29.00 \%$ and $750 \mathrm{mg} / \mathrm{ml}$ as $46.25 \%$ and $1000 \mathrm{mg} / \mathrm{ml}$ as $52.05 \%$.

Hence, this assay provided in sequence the reactivity of the samples with a constant free radical. A part of the examination on the method of the anti-oxidant activity, the capability of the compound to inhibit DPPH scavenging assay was studied. Among the 4 compounds, 1-(4-fluorophenyl)-3-(1Hindol-3-yl)prop-2-en-1-one (2) has highest antioxidant activity.

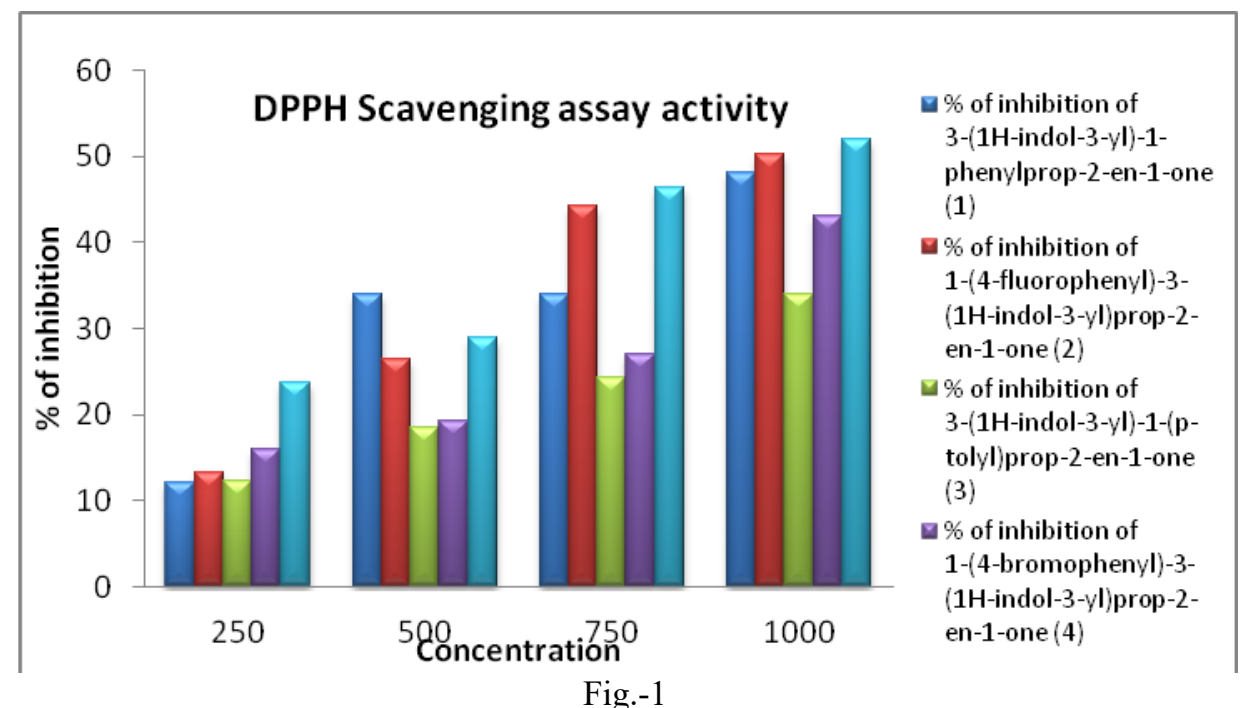


RASĀYAN J. Chem.

Vol. 14 | No. 1 |227-232| January - March | 2021

Table-1

\begin{tabular}{c|c|c|c|c}
\hline \multirow{2}{*}{ Compounds (\% of inhibition) } & \multicolumn{4}{|c}{ The concentration of the sample $(\mu \mathrm{g} / \mathrm{mL})$} \\
\cline { 2 - 5 } & 250 & 500 & 750 & 1000 \\
\hline 1 & 12.09 & 34 & 36 & 48 \\
\hline 2 & 13.25 & 26.5 & 44.2 & 50.3 \\
\hline 3 & 12.3 & 18.5 & 24.3 & 34 \\
\hline 4 & 16 & 19.2 & 27 & 43 \\
\hline Ascorbic acid (Standard) & 23.63 & 29 & 46.25 & 52.05 \\
\hline
\end{tabular}

\section{Anti-inflammatory Activity}

Albumen denaturation is a well-recognized cause of inflammation. Production of autoantigen in confident arthritic sickness is owing to denaturation of the protein. The method of denaturation involves a modification in electrostatic hydrogen, hydrophobic, and disulfide bonding. Aspirin was used as a standard anti-inflammation drug as shown in Table-2 and Fig.-2. The albumin denaturation technique was agreed at $100 \mu \mathrm{g} / \mathrm{ml} 200 \mu \mathrm{g} / \mathrm{ml}, 300 \mu \mathrm{g} / \mathrm{ml}, 400 \mu \mathrm{g} / \mathrm{ml}$ and $500 \mu \mathrm{g} / \mathrm{ml}$.

Compound 1 result shows the \% of cytotoxicity for $100 \mathrm{mg} / \mathrm{ml}$ as $42.2 \%, 200 \mathrm{mg} / \mathrm{ml}$ as $53.2 \%, 300$ $\mathrm{mg} / \mathrm{ml}$ as $56.3 \%, 400 \mathrm{mg} / \mathrm{ml}$ as $61.3 \%$ and $500 \mathrm{mg} / \mathrm{ml}$ as $71.3 \%$. Compound 2 shows the \% of cytotoxicity for $100 \mathrm{mg} / \mathrm{ml}$ as $36.4 \%, 200 \mathrm{mg} / \mathrm{ml}$ as $42.5 \%, 300 \mathrm{mg} / \mathrm{ml}$ as $54.7 \%, 400 \mathrm{mg} / \mathrm{ml}$ as $60.4 \%$ and $500 \mathrm{mg} / \mathrm{ml}$ as $66.6 \%$. Compound 3 result shows \% of cytotoxicity for $100 \mathrm{mg} / \mathrm{ml}$ as $34.3 \%, 200 \mathrm{mg} / \mathrm{ml}$ as $40.6 \%, 300 \mathrm{mg} / \mathrm{ml}$ as $52.8 \%, 400 \mathrm{mg} / \mathrm{ml}$ as $58.7 \%$ and $500 \mathrm{mg} / \mathrm{ml}$ as $68.9 \%$. Compound 4 shows the $\%$ of cytotoxicity for $100 \mathrm{mg} / \mathrm{ml}$ as $43 \%, 200 \mathrm{mg} / \mathrm{ml}$ as $54.3 \%, 300 \mathrm{mg} / \mathrm{ml}$ as $58.2 \%, 400 \mathrm{mg} / \mathrm{ml}$ as $63.5 \%$ and $500 \mathrm{mg} / \mathrm{ml}$ as $74.2 \%$.

These inhibition values are compared with Aspirin for $100 \mathrm{mg} / \mathrm{ml}$ as $45 \%, 200 \mathrm{mg} / \mathrm{ml}$ as $56.25 \%, 300$ $\mathrm{mg} / \mathrm{ml}$ as $66.20 \%, 400 \mathrm{mg} / \mathrm{ml}$ as $72.02 \%$ and $500 \mathrm{mg} / \mathrm{ml}$ as $82 \%$. Albumen Denaturation show significant change when the concentrations are $100 \mathrm{mg} / \mathrm{ml}, 200 \mathrm{mg} / \mathrm{ml}, 300 \mathrm{mg} / \mathrm{ml}, 400 \mathrm{mg} / \mathrm{ml}$ and $500 \mathrm{mg} / \mathrm{ml}$ for the compound isolated and \% of cytotoxicity values are compared with Aspirin.

The in-vitro studies of Anti-inflammatory activity indicate that the inhibition percentage of the compound by Albumen Denaturation method. Inhibition percentage is higher in compound 4 compared to other compounds.

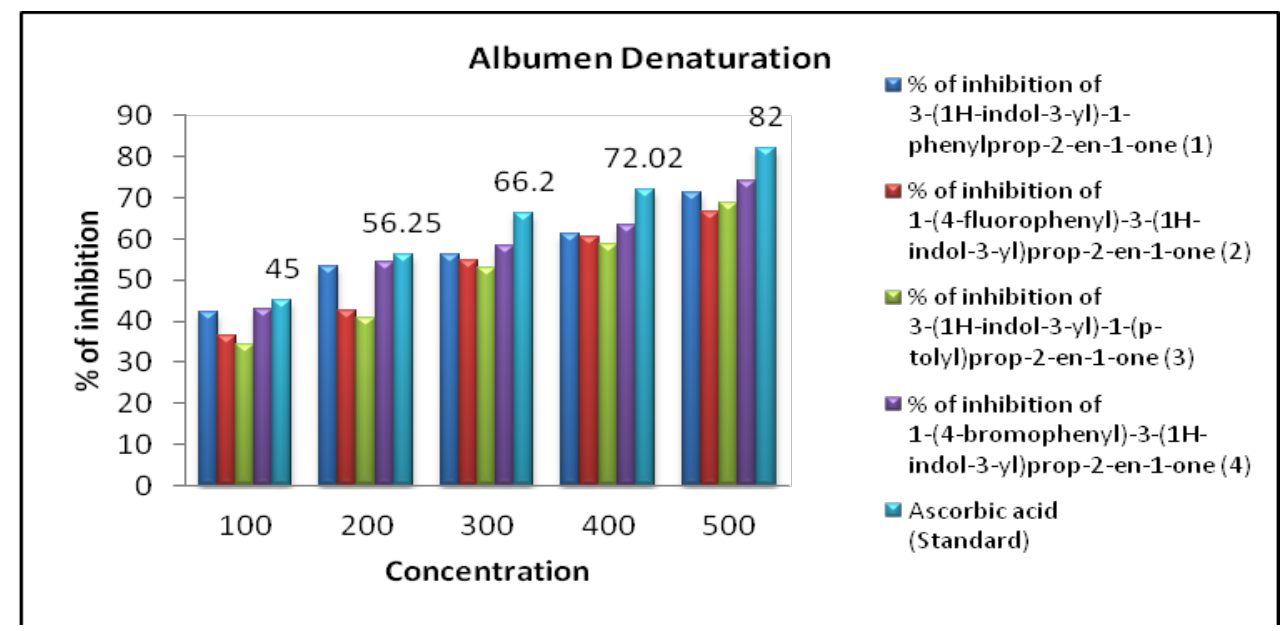

Fig.-2

Table-2

\begin{tabular}{c|c|c|c|c|c}
\hline \multirow{2}{*}{$\begin{array}{c}\text { Compounds } \\
\text { (\% of inhibition) }\end{array}$} & \multicolumn{5}{|c}{ Concentration of the sample $(\mu \mathrm{g} / \mathrm{mL})$} \\
\cline { 2 - 6 } & 100 & 200 & 300 & 400 & 500 \\
\hline 1 & 42.2 & 53.2 & 56.3 & 61.3 & 71.3 \\
\hline 2 & 36.4 & 42.5 & 54.7 & 60.4 & 66.6 \\
\hline 3 & 34.3 & 40.6 & 52.8 & 58.7 & 68.9 \\
\hline 4 & 43 & 54.3 & 58.2 & 63.5 & 74.2 \\
\hline Aspirin (Standard) & 45 & 56.25 & 66.2 & 72.02 & 82 \\
\hline
\end{tabular}

\section{Anti-Bacterial Activity}

The antibacterial studies of the synthesized compound using against E. coli, and $S$. aureus was investigated using the anti-bacterial drug of Chloromphenicol as a comparable control. From the value 
RASĀYAN J. Chem.

Vol. 14 | No. 1 |227-232| January - March | 2021

in Table-3 and Fig.-3 and Fig.-4, antibacterial activity E. coli and S. aureus of synthesized compounds by disc dispersion method, antibacterial activity of synthesized compounds are possible to be well connected with its decreased dimension and figure due to enlarged surface area with improved antimicrobial activities.

Table-3

\begin{tabular}{|c|c|c|c|c|c|c|c|c|}
\hline \multirow{3}{*}{$\begin{array}{c}\text { Compounds } \\
\text { (\% of Inhibition) }\end{array}$} & \multicolumn{8}{|c|}{ Organisms } \\
\hline & \multicolumn{4}{|c|}{ E. coli } & \multicolumn{4}{|c|}{ S. aureus } \\
\hline & 20 & 30 & 40 & Control & 20 & 30 & 40 & Control \\
\hline 1 & 12 & 15 & 17 & \multirow{4}{*}{18} & 14 & 18 & 20 & \multirow{4}{*}{22} \\
\hline 2 & 13 & 14 & 18 & & 12 & 16 & 19 & \\
\hline 3 & 9 & 12 & 16 & & 13 & 16 & 21 & \\
\hline 4 & 14 & 17 & 21 & & 15 & 18 & 20 & \\
\hline
\end{tabular}

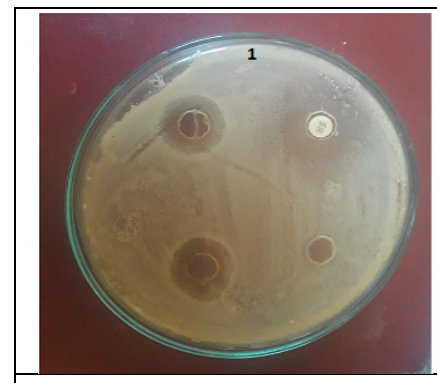

3-(1H-indol-3-yl)-1phenylprop-2-en-1-one

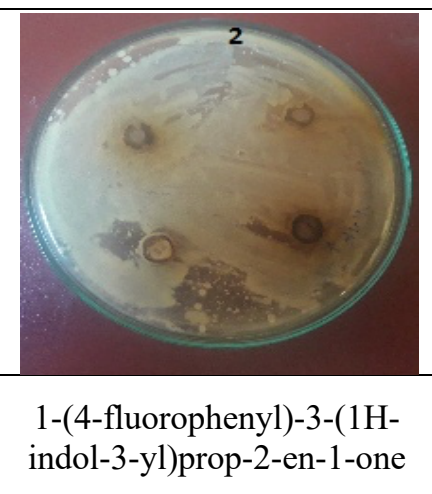

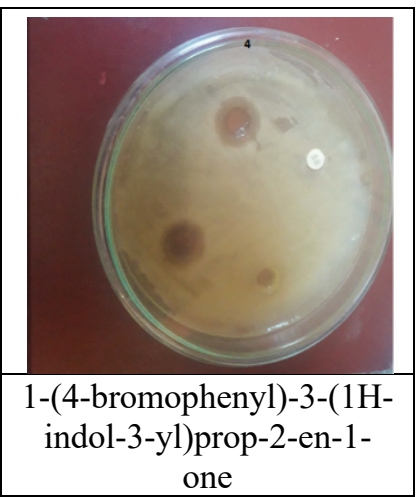
one

Fig.-3

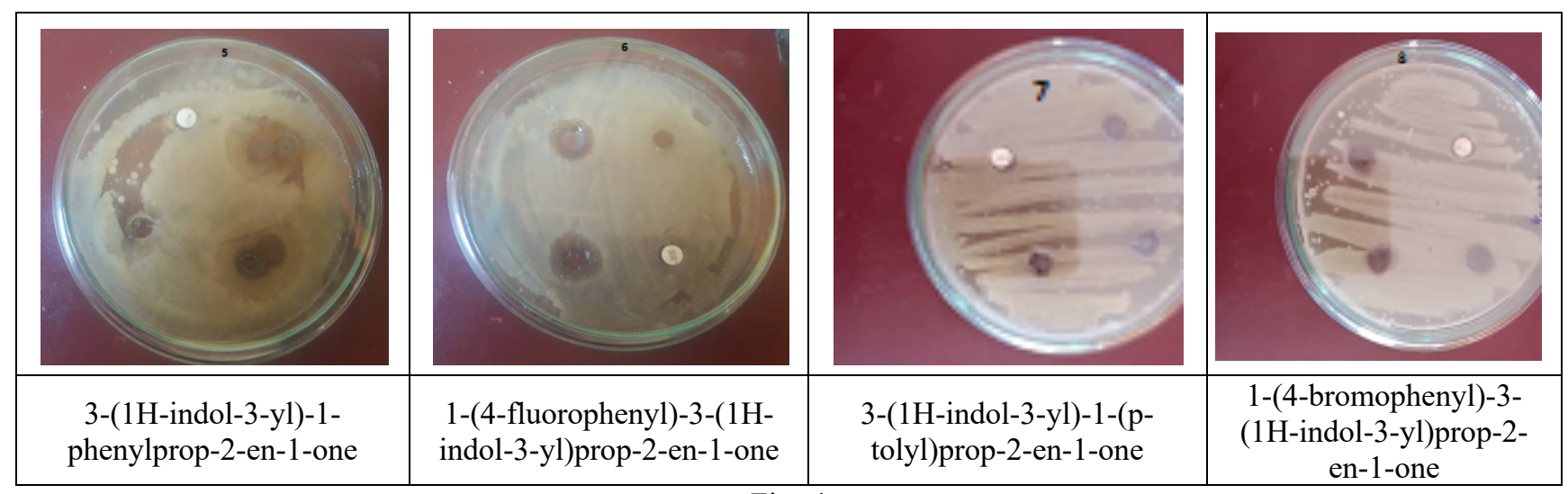

Fig.-4

\section{CONCLUSION}

Among the 4 compounds, 1-(4-fluorophenyl)-3-(1H-indol-3-yl)prop-2-en-1-one 2 has highest anti-oxidant activity. In-vitro studies of Anti-inflammatory activity indicate that the inhibition percentage of the compound by the Albumen Denaturation method. Inhibition percentage is higher in compound 4 compared to other compounds. Antibacterial results revealed that the E.coli, and $S$. aureus are may be more beneficial than the aerial parts against infectious diseases. Further investigations are showing huge inhibitory action against various microorganisms.

\section{ACKNOWLEDGMENT}

Special thanks to Dr. P. Iniyavan, Post Doctoral Fellow, Department of Chemistry, Jawaharlal Nehru Centre for Advanced Scientific Research (JNCAR), Bangalore, for providing an NMR facility and also for helping me to complete the bioactivity tests.

\section{REFERENCES}

1. M.C. Rodrıguez-Arguelles, E.C.L. Opez-Silva, J. Sanmartın, P. Pelagatti, and F. Zani, Journal of Inorganic and Biochemistry, 99(11), 2231 (2005), DOI:10.1016/J.JINORGBIO.2005.07.018 
RASĀYAN $J$. Chem.

Vol. 14 | No. 1 |227-232| January - March | 2021

2. T.C. Leboho, J.P. Michael, W.A L. Van Otterlo, S.F. Van Vuuren and C.B. de Koning, Bioorganic \& Medicinal Chemistry Letters, 19(17), 4948(2009), DOI:10.1016/J.BMCL.2009.07.091

3. R.C. Larock and E.K. Yum, Journal of American Chemical Society, 113, 6689(1991), DOI: 10.1021/JA00017A059

4. S.L. Cui, J. Wang, and Y.G. Wang, Journal of American Chemical Society, 130, 13526(2008), DOI: $10.1021 / \mathrm{JA} 805706$

5. M.C. Fagnola, I. Candiani and G. Visentin, Tetrahedron Letters, 38, 2307(1997), DOI:10.1016/S0040-4039(97)00300-6

6. D. Lee, C. Cho, J. Kim, Y. Youn, S. Shim and H. Song, Bulletin of the Korean Chemical Society, 17, 1132 (1996). Published: 1996.12.20

7. R. Haugland, J. Yguerabide and L. Stryer, Proceedings of the National Academy of Science, 63, 23 (1969), DOI:10.1073/PNAS.63.1.23

8. V. M. Moreira, J.A.R. Salvador, A.M. Beja and J.A. Paixao, Steroids, 76, 582(2011), DOI: 10.1016/J.STEROIDS.2011.02.009

9. L. Figueroa-Valverde, F. D'1az-Cedillo and E. Garc'ia-Cervera, Bulgarian Chemical Communications, 44, 83 (2012).

10. R. De Vincenzo, G. Seambla, P. Panici, Benedess and F.O. Remelletti, Anticancer Drug Design, 10, 481(1995).

11. L. Rongshi, C. Xiaowa, G. Baougng and J.N. Dominguez, Journal of Medicinal Chemistry, 38, 5031(1995), DOI:10.1021/JM00026A010

12. V.M. Gaurav and D.B. Ingle, Indian Journal of Chemistry, 25, 868(1986).

13. V.S. Parmar and C.S. Jain, Indian Journal of Chemistry Section B., 37, 628 (1988).

14. S.R. Modi and H.B. Naik, Oriental Journal of Chemistry, 10, 85(1994).

15. Nissan Chemical Industries Ltd., Japan Kokai Tokkyo Koho Japan, 3808035 (1983).

16. Sunil Kumar and Ritika, Future Journal of Pharmaceutical Sciences, 6, 121(2020), DOI: 10.1186/S43094-020-00141-Y

17. S. Lakhdar, M. Westermaier, F. Terrier, R. Goumont, T. Boubaker, A.R. Ofial and H. Mayr, Journal of Organic Chemistry, 71, 9088(2006), DOI:10.1021/jo702591p

18. V. Sharma, K. Pradeep and P. Devender, Journal of Heterocyclic Chemistry, 47, 491 (2010), DOI:10.1002/JHET.349

[RJC-6048/2020] 